\title{
The Effect of Counseling with Lecture and Leaflet Methods on Knowledge and Attitudes of Pregnant Women in Providing Basic Immunization
}

\author{
Eka Purnamasari ${ }^{1}$, Namora Lumongga Lubis ${ }^{2}$,Taufik Ashar ${ }^{2}$ \\ ${ }^{I}$ Alumni of the Master Program in Public Health Sciences, Universitas Sumatera Utara, Indonesia \\ ${ }^{2}$ Faculty of Public Health, Universitas Sumatera Utara, Indonesia \\ ekapurnamasari268@yahoo.com
}

\begin{abstract}
Complete basic immunization coverage in Labuhan District is still low at $71.15 \%$. Therefore, counseling is needed to change the behavior of parents in complete basic immunization to toddlers. The aim of this study was to determine the effect of counseling using the lecture method and the lecture method accompanied by leaflets on changes in maternal behavior in providing complete basic immunization at the Santosa Bay Health Center in Labuhanbatu Regency. This type of research is Quasi Experiment Design, with the design of Non-Equivalent Control Group. The intervention group consisted of two research subjects who were given different treatments and one research subject was made into the control group. This research was carried out in the work area of the Santosa Bay Health Center in LabuhanBatu Regency. The population in the study were all Trisemester III Pregnant Women as many as 188 people and the sample in this study were 75 people. Data analysis used included T-dependent, Wilcoxon, and Kruskal Walis. The results showed that there were differences $(p=<0.001)$ and attitudes $(p=$ $<0.001)$ about basic immunization with the lecture method. There are differences in knowledge $(p=<0.001)$ and attitudes $(p=$ $<0.001)$ with the lecture method accompanied by leaflets. There is a significant difference between the increase in knowledge and attitudes that get treatment counseling using the lecture method and the lecture method accompanied by leaflets. Changes in knowledge and the highest attitude on the group given the lecture accompanied by leafleat. For Teluk Sentosa Health Center, Labuhanbatu Regency, it should make a program with a routine schedule in the implementation of counseling for pregnant women both on basic immunization or related to the health and safety of mothers and babies. Where is the lecture method either without using media or by using alternative methods in implementing the program.
\end{abstract}

Keywords

Effect; counseling; leaflet methods; pregnant; basic immunization

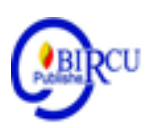

\section{Introduction}

Immunization is an attempt to provide immunity to infants and children by introducing vaccines into the body so that the body makes anti-substances to prevent certain diseases. The purpose of immunization is to stimulate the body's immunological system to form specific antibodies so that it can protect the body from attacks that can be prevented by immunization (PD3I) (Delan Astrianzah and Margawati, 2011).

Immunization is also a primary prevention effort that is very effective to avoid contracting an infectious disease. Thus, the incidence of infectious diseases will decrease, the resulting disability and death will decrease (WHO, 2007). 
Healthy Indonesia 2015 is the target of various programs contained in the MDGs. One of the programs is to reduce the under-five mortality rate by two-thirds between 1990 and 2015. To fulfill this program, the two indicators are in the form of under-five mortality and measles immunization coverage at the age of one year. The under-five mortality rate in 1990 was 97 per 1000 live births. Coverage of measles immunization in one year old children continues to increase every year in order to achieve the MDG target of 90 percent in 2015.

According to Minister of Health Decree No.482 / MENKES / SK / IV of 2010, data from several survey results indicate that community access to immunization programs as measured by BCG and DPT coverage is good enough, but the problem is generally the high drop out rate. Infants who have received the first immunization do not complete their basic immunizations, for example 20 percent drop out from BCG to DPT3, 18 percent dropped out from DPT1 to DPT3 (2007 Survey Data). This figure illustrates that there are around one million Indonesian babies who do not get complete immunizations each year.

Achievement of villages with UCI in North Sumatra Province in 2013 which was 68.98 percent decreased compared to 2012 which was 74.19 percent; slightly increased compared to 2011 which was 65.87 percent, and still below the national target of 80 percent. Regencies / Cities whose villages have reached UCI of at least 80 percent are nine Regencies / Cities namely Karo, Deli Serdang, Langkat, Humbang Hasundutan, Pakpak Bharat, Serdang Bedagai, North Nias and Medan. This number has decreased compared to 2012, which is 15 (fifteen) districts / cities, namely South Tapanuli, Toba Samosir, Labuhan Batu, Asahan, Simalungun, Deli Serdang, Langkat, Humbang Hasundutan, Pakpak Bharat, Serdang Bedagai, North Nias and Medan. This number has decreased compared to 2012 which is 15 (fifteen) districts / cities namely South Tapanuli, North Nias, Tebing Tinggi City and Medan City. Thus there are seven districts / cities where 80 percent of villages / kelurahan have reached UCI in 2012 but in 2013 experienced a decline, namely South Tapanuli District, Toba Samosir, Labuhan Batu, Asahan, Simalungun, Batubara and Tebing Tinggi; in fact there are two districts namely West Nias and South Nias where none of the villages / kelurahan reaches UCI. Such a condition can certainly be an opportunity to become an enclave in a PD3I outbreak as well as a hard homework assignment in the coming year (Health Profile of North Sumatra; 2013).

Five provinces have complete basic immunization coverage for infants below the provincial average $(48.4 \%)$. The province with the highest complete basic immunization coverage for infants as of September 2014 was Bangka Belitung Island (60.0\%) and lowest in North Sumatra $(36.5 \%)$. Likewise, the province with the highest coverage of measles in Sumatra's highest infant region is Bangka Belitung Island (59.8\%) and lowest in North Sumatra (41.9\%). And coverage of measles immunization in infants in North Sumatra Province as of September 2014 was 41.9 percent with the highest regency / city namely Pakpak Bharat (78.4\%) and the lowest north Nias (9.4\%) while Labuhanbatu Regency was still in 10th place the highest (38.1\%) (North Sumatra Health Office; 2014).

Hsb Maryam (2020) states that the existence of Public Health Center in the community is very important because the Public Health Center are the spearhead of health services provided by local governments. Individual health efforts at Public Health Center are related to sick behavior and treatment seeking behavior in sick people. In Labuhan Batu Regency in the immunization program with coverage of 9,124 infants, it is known that those who received BCG immunization were (76.47\%), DPT1 + HB1 immunization was (72.85) \%), DPT3 + HB3 immunization (69.15\%), Polio3 immunization (73.58\%), Measles immunization (72.4\%), and Hepatitis B3 immunization by (62.45\%) (Labuhanbatu Health Office, 2014). Basic immunization coverage in the working area of Sentosa Bay Public Health Center with a total of 732 babies, where BCG immunization is (875.2\%), DPT1 + HB1 immunization (73.1\%), 
DPT3 + HB3 immunization (73.9\%), Polio3 immunization (77.3\%), Measles immunization $(65.7 \%)$, and Hepatitis B3 immunization of that size, researchers are interested in examine the effect of counseling with the lecture method accompanied by leaflet media on changes in maternal behavior in providing basic immunizations in the Work Area of Sentosa Bay Public Health Center in Labuhanbatu Regency in 2019.

\section{Research Methods}

This type of research is a Quasi Experiment Design, with a Non Equivalent Control Group design. This research was conducted in the working area of Sentosa Bay Public Health Center in Labuhanbatu Regency. The population in the study were all 137 third trimester pregnant women and the sample in this study were 75 people. Analysis of the data used included T-dependent, Wilcoxon, and Kruskal Walis.

\section{Discussion}

Table 1. Distribution of Counseling Groups on Basic Immunizations by Age, Education and Income

\begin{tabular}{|l|c|c|c|c|c|c|}
\hline & \multicolumn{6}{|c|}{ Income } \\
\hline & \multicolumn{2}{|c|}{ Lecture Group } & \multicolumn{2}{c|}{ Lecture +Leaflet } & \multicolumn{2}{c|}{ Control group } \\
\hline Aged & $\mathrm{n}$ & $\%$ & $\mathrm{n}$ & $\%$ & $\mathrm{n}$ & $\%$ \\
\cline { 2 - 7 } 19-24 Years & 8 & 32,0 & 9 & 36,0 & 10 & 40,0 \\
24-32 Years & 17 & 68,0 & 16 & 64,0 & 15 & 60,0 \\
\hline Education & & & & & & \\
SMP & 3 & 12.0 & 3 & 12,0 & 2 & 8,0 \\
SMA & 19 & 76,0 & 20 & 80,0 & 20 & 80,0 \\
PT & 3 & 12,0 & 2 & 8,0 & 3 & 12,0 \\
\hline Income & & & & & & \\
<Rp. 2.000.000 & 15 & 60,0 & 14 & 56,0 & 15 & 60,0 \\
$\geq$ Rp. 2.000.000 & 10 & 40,0 & 11 & 44,0 & 10 & 40,0 \\
\hline
\end{tabular}

Based on Table 1 it can be seen that the number of respondents in the three groups each numbered 25 people, so overall the respondents were 75 mothers. In addition, it is also known that from the three groups, the majority of respondents aged 19-24 years old included eight people (32.0\%) in the lecture group, nine people (36.0\%) in the lecture group and 36 in the control group. 10 people $(40.0 \%)$. Education of respondents in the three groups also stated that the majority of high school educators included 19 people $(76.0 \%)$ in the lecture group, 20 people $(80.0 \%)$ in the lecture group and 80 people in the control group (80.0) \%). The respondents' income in the three groups also stated that the majority of the income was less than Rp. 2,000,000 among others in the lecture group were 15 people $(60.0 \%)$, in the lecture group accompanied by leaflets were 14 people $(56.0 \%)$ and in the control group were 15 people $(60.0 \%)$. 
Table 2. Differences in knowledge of pregnant women between before and after counseling treatment in each group

\begin{tabular}{|c|c|c|c|}
\hline Knowledge & Pre & Post & $\mathrm{p}$ \\
\hline Lecturer & $8,44 \pm 2,89$ & $12,12 \pm 3,15$ & $<0,001^{\mathrm{a}}$ \\
\hline $\begin{array}{l}\text { Lecturer + } \\
\text { Leaflet }\end{array}$ & $8,56 \pm 2,72$ & $14,48 \pm 2,66$ & $<0,001^{a}$ \\
\hline Control & $8,64 \pm 3,01$ & $8,48 \pm 3,01$ & $0,757^{\mathrm{a}}$ \\
\hline
\end{tabular}

${ }^{\mathrm{a}}$ T-Dependent

From the table below it can be seen in the Lecture group that the value of $p(0,000)$ is less than (0.05), so it can be concluded there is a significant difference between the knowledge of pregnant women before and after counseling using the lecture method. As for the knowledge of pregnant women in the lecture method group accompanied by leaflet media, the $\mathrm{p}$ value $(0.000)$ is smaller than $(0.05)$, so it can be concluded that there is a significant difference between the knowledge of pregnant women before and after counseling using the lecture method accompanied by leaflet media. For groups not getting counseling treatment about basic immunization, the $p$ value $(0.757)$ is greater than $(0.05)$, so it can be concluded that there is no significant difference between the knowledge of pregnant women who do not get treatment (control group).

Table 3. Differences in Attitudes of Pregnant Women between Before and After Counseling

\begin{tabular}{|c|c|c|c|}
\hline Attitudes & $\begin{array}{l}\text { in Eac } \\
\text { Pre }\end{array}$ & Post & p. \\
\hline Lecturer & $68,52 \pm 14,55$ & $85,8 \pm 8,50$ & $<0,001^{\mathrm{a}}$ \\
\hline $\begin{array}{c}\text { Lecturer }+ \\
\text { Leaflet }\end{array}$ & $70,16 \pm 10,27$ & $88,12 \pm 4,09$ & $<0,001^{\mathrm{a}}$ \\
\hline Control & $68,04 \pm 9,76$ & $68,92 \pm 9,53$ & $0,147^{\mathrm{a}}$ \\
\hline
\end{tabular}

From the table above it can be seen in the group using the lecture method) that a $\mathrm{p}$ value $(0.000)$ is less than $(0.05)$, so it can be concluded that there is a significant difference between the attitude of pregnant women about basic immunization before and after counseling using the lecture method. As for the attitude of pregnant women in the group using the accompanied lecture leaflet method media obtained $p$ value $(0.000)$ smaller than (0.05), then it can be concluded that there are significant differences between the attitudes of pregnant women before and after counseling by using the lecture method accompanied by leaflet media. For the control group that did not receive counseling treatment about basic immunization, $p$ values $(0.147)$ were greater than $(0.05)$, so it can be concluded that there were differences between the attitudes of pregnant women who did not receive treatment (control group).

Table 4. Differences in Knowledge of Pregnant Women After Treatment Outreach in Each

\begin{tabular}{lcccc}
\multicolumn{3}{c}{ Group } & \\
\hline Pengetahuan & Mean \pm SD & $\mathrm{p}^{*}$ & Ceramah & Kontrol \\
Ceramah & $3,68 \pm 3,02$ & $<0,001$ & $\frac{+ \text { Leaflet }}{0,023}$ & $<0,001$ \\
Ceramah + Leaflet & $5.92 \pm 3,05$ & & & $<0,001$ \\
Kontrol & $\underline{-0,16 \pm 2,56}$ & & & \\
* Kruskal Wallis & & & &
\end{tabular}


From the table above it can be seen in the comparison of knowledge in the lecture group and the lecture group with leaflets obtained with a $\mathrm{p}$ value $(0.023)$ greater than $(0.05)$, it can be concluded that there is a difference between increased knowledge of pregnant women in the group using the lecture method and the group that using the lecture method accompanied by leaflets.

Whereas for comparison of knowledge of pregnant women about basic immunization in the lecture group with the control group obtained a value with a p value $(0,000)$ smaller than (0.05), it can be concluded that there is a significant difference between increasing the knowledge of pregnant women about basic immunization receiving counseling treatment using lecture method with the knowledge of pregnant women about basic immunizations that do not get treatment (control group).

Table 5. Differences in Attitudes of Pregnant Women After the Extension Treatment in Each Group

$\begin{array}{lllll}\text { Sikap } & \text { Mean } \pm \text { SD } & p^{*} & \begin{array}{l}\text { Ceramah } \\ \text { Koeaflet }\end{array} & \text { Kontrol } \\ \text { Ceramah } & 17,28 \pm 13,60 & <0,001 & \frac{1,000}{1,000} & <0,001 \\ \text { Ceramah +Leaflet } & 17,96 \pm 11,37 & & & <0,001\end{array}$

Kontrol $\quad 0,88 \pm 2,93$

*Kruskal Wallis

From the table above it can be seen in the comparison of attitudes in the lecture group and the lecture group with leaflets obtained with a $\mathrm{p}$ value $(1,000)$ greater than $(0.05)$, it can be concluded that there is no difference between increasing the attitudes of pregnant women in groups using the lecture and group methods who used the lecture method accompanied by leaflets.

As for the comparison of the attitudes of pregnant women about basic immunization in the lecture group with the control group, the value of $p(0.000)$ is greater than $(0.05)$, so it can be concluded that there is a significant difference between increasing attitudes of pregnant women about basic immunization receiving counseling treatment using lecture method with the attitude of pregnant women about basic immunization that does not get treatment (control group). Attitude means the way people think and feel about someone or something; a feeling or way of thinking that affects a person's behavior or a way of thinking and behaving that people regard as unfriendly, rude, etc (Sari, 2020).

According to Arysha (2020) Women are one important element in a family or community. Therefore, women's health, especially their reproductive health, is one of the important health problems. Differences in knowledge and attitudes of pregnant women before and after the implementation of counseling using the lecture method. There are several forms of methods that can make participants (hearings) more active in the implementation of health counseling besides lecture methods including group discussions, FGD (focus group discussions), buzz groups, role play and simulations. All the methods above are expected to be able to increase the knowledge and attitudes of participants over those that only have oneway communication (Notoatmodjo, 2007).

Based on the results obtained in this study, the average knowledge and attitudes of pregnant women regarding the provision of basic immunizations on pretest is 8.44 and 68.52 with standard deviations of 2.89 and 14.55. At the time of the posttest, the average knowledge and attitude of pregnant women was 12.12 and 85.8 with a standard deviation of 3.15 and 8.50. based on this we can get information on differences in values with the 
knowledge and attitudes of pregnant women between pretest and posttest are 3.68 and 17.28 with a standard deviation of 3.02 and 913.6- Dependent $t$ test results obtained $p$ value $=0,000$ this value is smaller than the value of $\alpha$ (alpha) of 0.05 . thus it can be concluded that there is a significant difference in the knowledge of pregnant women before and after the implementation of counseling to the group with the mirror method with a value of thit = 4.795. As for the attitudes of pregnant women in the lecture group, there were differences in the attitudes of pregnant women about basic immunization before and after counseling with the lecture method with a value of $p(0,000)$ with a value of thit $=-4,902$

Differences in knowledge and attitudes of pregnant women towards basic immunization in the lecture method group accompanied by media leaflets. Mother's knowledge of immunization is a very important factor, so that mothers can be responsive and know what to do when side effects occur to their children to get complete coverage of immunization (Sarfaraz, 2017). Lack of knowledge of parents, especially mothers will bring negative attitudes and fear of immunization side effects which will later have an impact on the views of mothers and the willingness of mothers to take their children to health facilities for immunization. So there are mothers who are of the view that immunization will be detrimental to their children (Septiarini, 2015).

The lecture method is the most traditional and long-run method of teaching in an effort to transmit knowledge orally or lecture. This method is sometimes boring so in practice it requires certain skills. How to teach a lecture can also be said as a lecture technique, is a way of teaching used to convey information or information, or a description of an issue orally (Roestyah, 2011).

The average knowledge and attitude of pregnant women about giving basic immunization to children at the time of the pretest is 8.56 and 70.16 with a standard deviation of 2.72 and 10274. At the time of the posttest the average student's knowledge was 14.48 and 88.12 with a standard deviation of 2.66 and 4.09 . Dependent t test results obtained p value 0,000 , this value is smaller than the value of $\alpha$ (alpha) of 0.05 . Thus it can be concluded that there are differences in knowledge of pregnant women about basic immunization before and after counseling is carried out by the lecture method accompanied by media leaflets with a value of $\mathrm{p}(0,000)<(0.05)$. While the attitudes of pregnant women obtained results there were significant differences in the attitudes of pregnant women about basic immunization before and after counseling was carried out using the lecture method accompanied by a leaflet with a $\mathrm{p}$ value $(0,000)<(0.05)$.

The results of this study are consistent with research conducted by Aprida (2015) that the provision of health education accompanied by leafleats about TT immunization is effective in increasing the knowledge of pregnant women about TT immunization. The results showed better knowledge after receiving leaflets. The results of this study also strengthen Muslikha and Purwanti's (2011) research on the Role of the Exclusive ASI Leaflets on Mothers' Knowledge of Exclusive ASI and Motivation to Support Exclusively in BPS NY. Djuwedah Kebasen, Banyumas Regency. The results showed that the leaflet had a role in increasing maternal knowledge about exclusive breastfeeding and motivation mother to breastfeed exclusively. The results of Dewi Susantu's research (2019) stated that there were differences in the effectiveness of health promotion with leaflet and slide media on the knowledge and attitudes of mothers regarding the Rubles Measles Immunization.

Differences in knowledge and attitudes of pregnant women towards basic immunization in the control group (without treatment). The average knowledge and attitude of pregnant women about giving basic immunization to children in the control group at the time of the pretest was 8.60 and 65.28 with a standard deviation of 3.17 and 12,249 At the time of the 
posttest the average student's knowledge is obtained 9.28 and 67.60 with standard deviations of 3.19 and 10.96 .

Dependent $t$ test results there is no significant difference in the knowledge of pregnant women about basic immunization if they do not get treatment in the form of counseling about basic immunization with a value of $\mathrm{p}(0.177)>(0.05)$. While the attitudes of pregnant women obtained the results there are differences in the attitudes of pregnant women about basic immunization even though they do not get counseling treatment about basic immunization with a value of $\mathrm{p}(0.038)>(0.05)$.

From the above results, it was found that among the three groups that had the most significant value difference between knowledge and attitudes towards pregnant women was to use the lecture method accompanied by media leaflets. The lecture method with this leaflet was given to the group of respondents who were pregnant so there was a separate motivation for listen to information from the lecture method and add information by reading obtained from the leaflet media.

Differences in increasing knowledge and attitudes of pregnant women regarding basic immunization in the three groups. The immunization program is one of the efforts of health services that aims to reduce morbidity, disability and death from diseases, especially in infants which can increase active immunity against a disease. The short term goal of immunization is to prevent individual and group diseases while the long-term goal is the elimination of a disease (Ponidjan, 2012).

Based on the results of the study showed that there was a difference between increased knowledge of pregnant women on basic immunization, in the group of pregnant women who received counseling about basic immunization by lecture method and lecture method with leaflet media ( $p(0.023)>(0.05)$. attitudes the results of the comparison of attitudes in the group lecture and group lectures accompanied by leaflets obtained values with a value of $\mathrm{p}=$ $1,000>(0.05)$, thus there is no difference in attitudes of pregnant women about basic immunization in groups using the lecture method and groups using the lecture method accompanied leaflet.

For comparison of knowledge of pregnant women about basic immunization in groups lecture accompanied by a leaflet with the control group obtained a value with a value of $\mathrm{p}=$ $0.0001<(0.05)$ thus there is a significant difference between the knowledge of pregnant women about basic immunization who received counseling treatment using the lecture method with the knowledge of pregnant women about basic immunization that did not get treatment (control group). Comparison of the attitudes of pregnant women regarding basic immunization in the lecture group accompanied by leaflets with the control group obtained a value of $p=0,0001<(0.05)$ thus there is a significant difference between the attitudes of pregnant women about basic immunization receiving counseling treatment using the lecture method with knowledge of pregnant women about basic immunizations that do not get treatment (control group).

Based on the results of the study showed that there was an increase in the knowledge of pregnant women on basic immunization, in the group of pregnant women who received counseling about basic immunization by the lecture method accompanied by leaflets with the group not receiving treatment (control group) with a value of $p=0,000<(0.05)$. In increasing attitudes the results of comparison of attitudes in the lecture group accompanied by leaflets and groups that did not get treatment (control group) obtained values with a value of $\mathrm{p}=0.023<(0.05)$, thus differences in attitudes of pregnant women about basic immunization in groups that use the lecture method accompanied by leflets and groups that do not get treatment (control group). 
In this study also obtained information that there is no difference in the increase in knowledge and attitudes of pregnant women. This is in line with the results of statistical tests of knowledge and attitudes of reliable mothers before and after the implementation of counseling. Because based on statistical tests the results obtained are the absence of differences in knowledge and attitudes of pregnant women towards the provision of meaningful basic immunization between the lecture method group and the lecture method with leaflet media before and after counseling. That is because one of them is another factor not examined in this study that affects people's knowledge and attitudes including perception, motivation and experience. In this study also in the provision of counseling by the lecture method performed on every pregnant woman who in the third trimester without regard to whether the pregnancy is the first child, second or so on. Because there are differences in experience and knowledge between mothers who are pregnant with their first child or mothers who are pregnant with their second, third or so on children. Thus affecting the level of knowledge and attitudes of pregnant women so that differences in increasing knowledge and attitudes of pregnant women towards basic immunization.

\section{Conclusion}

There is differences in knowledge and attitudes before and after counseling about basic immunization by the lecture method. There is differences in knowledge and attitudes before and after counseling about basic immunization by the lecture method accompanied by leaflets. There is differences in attitudes before and after counseling about basic immunization with the lecture method. There is a difference between increased knowledge and attitudes of pregnant women in the group using the lecture method and the group using the lecture method accompanied by leaflets. There is a significant difference between increasing knowledge and pregnant women about basic immunization receiving treatment counseling using the lecture method with those not getting treatment (control group). There is a difference between increasing knowledge and attitudes of pregnant women who receive counseling treatment with the lecture method accompanied by media leaflets with groups of pregnant women who do not get treatment.

\section{References}

Arysha, V.O., Santosa, H. and Sanusi, S.R. (2020). The Effect of Extrinsic Motivation on Housewife Actionsin IVA Testin the Working Area of Community Health Center at Bandar Kalipah. Britain International of Exact Sciences (BIoEx) Journal, 352-356.

BPPK Kemenkes RI. 2013. Riset kesehatan dasar 2013. BPPK Kemenkes RI. Jakarta.

Depkes RI. 2005 Pedoman Teknis Imunisasi Tingkat Puskesmas. Diakses dari http://www.depkes.go.id/do wnload.php?file=download/ pusdatin/profil-kesehatanindonesia/profil-kesehatan- indonesia-2005.pdf

Dinas Kesehatan Propinsi Sumatera Utara. 2014. Profil Kesehatan Provinsi Sumatera Utara, Dinas Kesehatan Provinsi Sumatera Utara, Medan.

Hsb Maryam, S., Santosa, H. and Asfriyati. (2020). Relationship of Family Income and Family Support with Maternal Reference in Pregnant Women in Pantai Cermin BEmONC, Langkat District, 2019. Budapest International Research and Critics Institute (BIRCI-Journal) : Humanities and Social Sciences, 486-493.

Notoatmodjo, S. (2005). Promosi kesehatan: teori dan aplikasi. Jakarta: PT.Rineka Cipta.

Sanjaya, H.W. (2014). Srategi pembelajaran: berorientasi standar proses pendidikan. Jakarta: Prenada Media Group. 
Sari, I., Pulungan, A. H., and Husein, R. (2020). Students' Cognition and Attitude in Writing Descriptive Text. Britain International of Linguistics, Arts and Education (BIoLAE) Journal, 395-404.

Usman, U. (2000). Menjadi guru profesional. Bandung : PT.Rosyda Karya.

Wawan, A \& Dewi, M. (2014). Teori pengukuran pengetahuan, sikap dan perilaku manusia. Yogyakarta : Nuha Medika.

Zulkarimein. (1989). Prinsip- prinsip komunikasi untuk penyuluhan. Jakarta: Fak. Ekonomi Ul. 